While the facts do not permit us to assert that there is a definite association between these two diseases, there is sufficient evidence to call for a further close examination of the question.

\section{Summary}

Among 154 patients with Crohn's disease attending the Radcliffe Infirmary since 1938 there have been three with carcinoma of the colon. Case histories of these three patients are given.

If only the cases of Crohn's disease with evidence of colonic involvement are considered ( 82 patients) the frequency of carcinoma of the colon in this series is $3.7 \%$.

In reported series dealing with colonic disease, carcinoma of the colon has appeared to be infrequent except in one series with a frequency of $4.8 \%$.

The question of a possible association between Crohn's disease of the colon and carcinoma deserves further examination.
REFERENCES

Atwell, J. D., Duthie, H. L., and Goligher, J. C. (1965). Brit. J. Surg., $52,966$.

Bersack, S. R., Howe, J. S., and Rehak, E. M. (1958). Gastroenterology, 34, 703

Buchanan, D. P., Huebner, G. D., Woolvin, S. C., North, R. L., and Novack, T. D. (1959). Amer. 'f. Surg., 97, 336.

Cornes, J. S., and Stecher, M. '(1)61). Gut, 2, 189.

Crohn, B. B., and Yarnis, H. (1966). 7. Mt Sinai Hosp., 33, 503.

Edwards, F. C., and Truelove, S. C. (1964). Gut, 5, 1.

Edwards, H. (1964). 7. roy. Col. Surg. Edinb., 9, 115.

Fone, D. J. (1966). Med. F. Aust., 1, 8\$5.

Ginzburg, L., Schneider, K. M., Dreicon, D. H., and Levinson, C. (1956). Surgery, 39, 347

Hawk, W. A., and Turnbull. R. B. (196: Gastroenterology, 51, 802.

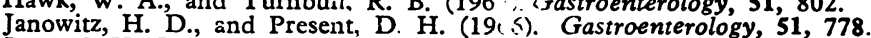

Jones, J. H., Lennard-Jones, J. E., and Lockhart-Mummery, H. E. (1966). Gut, 7, 448.

Kornfeld, P., Ginzburg, L., and Adlersburg, D (1957). Amer. F. Med., 23, 493 .

Lennard-Jones, J. E., and Stalder, G. A. (1967). Gut, 8, 332.

Lockhart-Mummery, H. E., and Morson, B. C. (1960). Gut, i, 87.

Lockhart-Murnmery, H. E., and Morson, B. C. (1964). Gut, 5, 493.

Van Patter, W. N., Bargen, J. A., Dockerty, M. B., Feldman, W. H., Mayo, C. W., and Waugh, J. M. (1954). Gast: :enterology, 26, 347,

Weingarten, B., Parker, J. G., Chazen, E. M., and Jac.uvson, H. G. (1959). Arch. Surg., 78, 483

Weingarten, B., and Weiss, J. (1960). Amer. 7. Gastruent., 33, 203.

Zisk, J., Shore, J. M., Rossoff, L., and Friedman, N. 8. ::960:. Surgery, 47, 970 .

\title{
Haemodynamic Effects of Lignocaine in Acute Myocardial Infarction
}

\author{
MARY STANNARD,* M.B., B.S., M.R.A.C.P.; GRAEME SLOMAN, † M.B., B.SC., M.R.C.P., M.R.C.P.EI ; F.R.A.C.F \\ LINNET SANGSTER $\ddagger$
}

Lignocaine (Xylocaine, Lidocaine) is now widely accepted as an antiarrhythmic agent, particularly in the management of ventricular tachycardia and ventricular ectopic beats occurring as complications of acute myocardial infarction (Frieden, 1965 ; Bedynek et al., 1966; Lown et al., 1967). Lignocaine is regarded as producing a low incidence of drug complications (Lown et al., 1967), but little information is available on its haemodynamic effects in patients with acute myocardial infarction.

\section{Methods and Materials}

Eight patients were studied, being selected from those admitted to the Coronary Care Unit of the Royal Melbourne Hospital with transmural myocardial infarction which had occurred within the previous 24 hours. Contraindications for admission to the study were cardiogenic shock or complete heart block. All the patients were men with an age range from 49 to 63 years, mean 57.5 years. They were classified as having had mild or severe infarction according to the criteria of Robinson et al. (1964), and on this basis three were mild and five severe cases. Papaveretum (Omnopon) was used as the analgesic where indicated, and all patients received oxygen by means of a face mask. None of the patients was studied until pain had been completely relieved; the nature of the study was explained to them and they were caused no obvious distress.

Fine plastic tubing (P.E.50) was introduced into the right median cubital vein through an 18-gauge thin wall needle and

- Research Assistant, Cardiac Department, the Royal Melbourne Hospital. Grant-in-aid No. G.428, National Heart Foundation of pital. Astralia.

f Director, Cardiac Laboratory, the Royal Melbourne Hospital.

¥ Cardiac Technician, Cardiac Department, the Royal Melbourne Hospital. Supported by a grant from the Felton Bequest. flow-guided catheterization performed as described by Dotter and Straube (1962). Pulmonary artery or right ventricular pressure and right atrial pressure were ascertained. The brachial artery was cannulated with a nylon cannula, ${ }^{1}$ using the Seldinger technique. Pressures were recorded by means of a Sanborn differential transformer transducer (267A) and a Sanborn 2-channel direct writing system (296 T.C.). Pressures were recorded with the patient lying in bed with the head raised on one pillow, the manubrium sterni being the point of reference.

Cardiac output was determined by a dye-dili:tion method, indocyanine green (Cardio-green) being used. The dye solution $N$ was injected rapidly into the right atrium via the venous catheter, and arterial blood was withdrawn from the brachial artery at a constant rate by a motor-driven pump. Recordings were obtained through a Waters X.301 densitometer and a Moseley 7035A X-Y recorder. The cardiac output was calculated from the curves so obtained, using a planimetric method (Dalby et al., 1967). The heart rate was determined by an electrocardiogram recorded simultaneously with the cardiac output studies.

Systemic blood pressure and duplicate estimations of cardiac output and heart rate were measured at rest, immediately after and 10 minutes after the intravenous injection of $100 \mathrm{mg}$. of lignocaine. In four cases blood pressure was monitored continuously during the administration of lignocaine and at intervals over the next 10-minute period. Pulmonary artery or right $尺$ ventricular pressure was measured at rest and at the completion of the study, approximately 15 minutes after the administration of lignocaine. The drug was injected over a five-minute period, the completion of the injection being taken as zero time.

\footnotetext{
${ }^{1}$ Portex nylon intravenous cannula, length 12 in. $(30 \mathrm{~cm}$.), outer diameter 0.052 in. $(1.3 \mathrm{~mm}$.).
} 


\section{Results}

The results are given in Tables I and II. There was very little change in blood pressure, heart rate, cardiac output, stroke

TABLE I

\begin{tabular}{|c|c|c|c|c|c|}
\hline \multirow{2}{*}{ Case No. } & \multicolumn{3}{|c|}{ Systolic Blood Pressure (mm. Hg.) } & \multicolumn{2}{|c|}{$\begin{array}{l}\text { Pulmonary Artery or Right } \\
\text { Ventricular Systolic } \\
\text { Pressure (mm. Hg.) }\end{array}$} \\
\hline & Rest & $\begin{array}{c}\text { Immediately } \\
\text { After } \\
\text { Lignocaine }\end{array}$ & $\begin{array}{l}10 \text { Minutes } \\
\text { After. } \\
\text { Lignocaine }\end{array}$ & Rest & $\begin{array}{l}15 \text { Minutes } \\
\text { After } \\
\text { Lignocaine }\end{array}$ \\
\hline $\begin{array}{l}1 \\
2 \\
3 \\
4 \\
5 \\
6 \\
7 \\
8\end{array}$ & $\begin{array}{l}110 / 55 \\
85 / 60 \\
175 / 115 \\
200 / 100 \\
175 / 100 \\
185 / 120 \\
125 / 75 \\
110 / 70\end{array}$ & $\begin{array}{c}100 / 55 \\
60 / 35 \\
175 / 110 \\
200 / 105 \\
180 / 110 \\
185 / 110 \\
125 / 75 \\
120 / 80\end{array}$ & $\begin{array}{c}85 / 45 \\
60 / 30 \\
160 / 100 \\
200 / 100 \\
185 / 105 \\
185 / 110 \\
125 / 75 \\
110 / 70\end{array}$ & $\begin{array}{l}35 \\
25 \\
22 \\
27 \\
17 \\
23 \\
20 \\
20\end{array}$ & $\begin{array}{l}35 \\
20 \\
20 \\
14 \\
24 \\
22 \\
20\end{array}$ \\
\hline Mean .. & $145 \cdot 6$ & $143 \cdot 1$ & $138 \cdot 7$ & $23 \cdot 6$ & $22 \cdot 1$ \\
\hline $\begin{array}{l}\text { Mean } \\
\text { S.E. } \\
\text { t. } \\
\text { D.F. } \quad \ldots \\
\text { D. }\end{array}$ & & $\begin{array}{l}0 \\
6 \mathrm{~ns}\end{array}$ & ns & \multicolumn{2}{|c|}{$\begin{array}{l}1 \cdot 71 \\
1 \cdot 27 \\
1 \cdot 35 \mathrm{~ns} \\
7\end{array}$} \\
\hline
\end{tabular}

ns $=$ Not Significant in agreement with those of Harrison et al. (1963), who showed that during cardiac surgery lignocaine in a dose of $1-2 \mathrm{mg} . / \mathrm{kg}$. body weight did not cause any significant circulatory depression. Austen and Moran (1965), however, using a dose of 0.5-30 mg./ kg. body weight in dogs, showed that lignocaine is a myocardial depressant. These discrepancies may be partly explained by the work of D'Amato and Truant (1955), who showed that lignocaine potentiates the action of adrenaline on blood pressure. It has been our experience in 20 patients (unpublished) and that of Valori et al. $(1967 \mathrm{a}, 1967 \mathrm{~b})$ that catecholamine excretion is increased after acute myocardial infarction, and it may be that the depressant effect of lignocaine is masked by the effect of endogenous catecholamine.

We therefore consider that lignocaine is a safe drug for use in the management of ventricular arrhythmias complicating acute myocardial infarction.

\section{Summary}

The haemodynamic effects of lignocaine (Xylocaine) $100 \mathrm{mg}$. I.V. were studied in eight patients with acute myocardial infarction. The drug was shown to have no significant effect on the

TABLE II

\begin{tabular}{|c|c|c|c|c|c|c|c|c|c|c|c|}
\hline \multirow{2}{*}{\multicolumn{3}{|c|}{ Case No. }} & \multicolumn{3}{|c|}{ Cardiac Output (litres/minute) } & \multicolumn{3}{|c|}{ Heart Rate/Minute } & \multicolumn{3}{|c|}{ Stroke Volume (ml.) } \\
\hline & & & Rest & $\begin{array}{l}\text { Immediately } \\
\text { After } \\
\text { Lignocaine }\end{array}$ & $\begin{array}{l}10 \text { Minutes } \\
\text { After } \\
\text { Lignocaine }\end{array}$ & Rest & $\begin{array}{l}\text { Immediately } \\
\text { After } \\
\text { Lignocaine }\end{array}$ & $\begin{array}{l}10 \text { Minutes } \\
\text { After } \\
\text { Lignocaine }\end{array}$ & Rest & $\begin{array}{c}\text { Immediately } \\
\text { After } \\
\text { Lignocaine }\end{array}$ & $\begin{array}{l}10 \text { Minutes } \\
\text { After } \\
\text { Lignocaine }\end{array}$ \\
\hline $\begin{array}{l}1 \\
3 \\
4 \\
5 \\
7 \\
8 \\
\end{array}$ & $\begin{array}{l}\frac{1}{2} \\
3 \\
4 \\
5 \\
7 \\
3\end{array}$ & & $\begin{array}{l}-3.8 \\
2.8 \\
6.6 \\
5.4 \\
4.7 \\
6.9 \\
5.5\end{array}$ & $\begin{array}{l}\overrightarrow{3.4} \\
3 \cdot 2 \\
6.9 \\
5.5 \\
4.6 \\
6.4 \\
4 \cdot 6\end{array}$ & $\begin{array}{l}- \\
3 \cdot 5 \\
2 \cdot 5 \\
6 \cdot 5 \\
5 \cdot 5 \\
4 \cdot 7 \\
6 \cdot 5 \\
4 \cdot 4\end{array}$ & $\begin{array}{r}70 \\
60 \\
79 \\
67 \\
95 \\
130 \\
65 \\
74 \\
\end{array}$ & $\begin{array}{r}85 \\
55 \\
85 \\
74 \\
97 \\
130 \\
65 \\
75\end{array}$ & $\begin{array}{r}\overline{55} \\
90 \\
70 \\
90 \\
130 \\
65 \\
75\end{array}$ & $\begin{array}{r}-63 \\
35 \\
99 \\
57 \\
36 \\
106 \\
74 \\
\end{array}$ & $\begin{array}{l}-\overline{62} \\
38 \\
93 \\
57 \\
35 \\
99 \\
61\end{array}$ & $\begin{array}{r}\overline{64} \\
28 \\
93 \\
61 \\
36 \\
100 \\
59\end{array}$ \\
\hline Mean & .. & . & $5 \cdot 1$ & 4.9 & $4 \cdot 8$ & $80 \cdot 0$ & $83 \cdot 2$ & $82 \cdot 1$ & $67 \cdot 1$ & $63 \cdot 5$ & $63 \cdot 0$ \\
\hline \multicolumn{3}{|c|}{$\begin{array}{ll}\text { Mean diff. } & \ldots \\
\text { S.E. } & \cdots \\
\text { t... } & \cdots \\
\text { D.F.. } & \cdots\end{array}$} & \multicolumn{2}{|c|}{$\begin{array}{l}1 \cdot 57 \\
1.77 \\
0.89 \mathrm{~ns} \\
6\end{array}$} & $\begin{array}{l}3.00 \\
1.50 \\
2.00 \mathrm{~ns} \\
6\end{array}$ & \multicolumn{2}{|c|}{$\begin{array}{l}3 \cdot 12 \\
2 \cdot 16 \\
1 \cdot 45 \mathrm{~ns} \\
7\end{array}$} & & \multicolumn{2}{|c|}{$\begin{array}{l}3 \cdot 57 \\
2 \cdot 04 \\
1.75 \mathrm{~ns} \\
6\end{array}$} & $\begin{array}{l}4 \cdot 14 \\
2 \cdot 41 \\
1 \cdot 72 \mathrm{~ns} \\
6\end{array}$ \\
\hline
\end{tabular}

ns-Not Significant

volume, and pulmonary artery or right ventricular pressure, and in no case was the effect of lignocaine statistically significant. In the four cases where blood pressure was monitored continuously there was little change. There was no significant difference between times for any of the five effects measured.

No side-effects arose from the intravenous administration of lignocaine. Though fits are a recognized complication of intravenous lignocaine, this complication was not observed from a dose of $100 \mathrm{mg}$. given over five minutes, nor were there any cerebral symptoms. None of the patients studied developed any significant arrhythmia during the period of monitoring in the coronary care unit. Two of the eight patients subsequently died, both of them in general medical ward beds on the tenth day after their acute episode.

\section{Discussion}

The dose of lignocaine recommended by Lown et al. (1967) for the initial treatment of ventricular arrhythmias is $50-100$ mg. I.V., treatment being continued with an I.V. infusion at the rate of $1-4 \mathrm{mg}$./minute. Our studies have shown that lignocaine in a dose of $100 \mathrm{mg}$. given intravenously over a period of five minutes has no effect on the haemodynamic state of patients with acute myocardial infarction. These results are cardiac output, heart rate, systemic blood pressure, and pulmonary artery pressure.

We wish to thank the honorary physicians of the Royal Melbourne Hospital, who allowed patients under their care to be studied. We thank the nursing staff of the coronary care unit; the cardiac technicians, Miss J. Miles and Mrs. W. French, who assisted with the haemodynamic studies; and Miss B. Laby, who kindly advised on the statistical treatment of the information.

\section{REFERENCES}

Austen, W. G., and Moran, J. M. (1965). Amer. F. Cardiol., 16, 701. Bedynek, J. L., jun., Weinstein, K. N., Kah, R. E., and Minton, P. R. (1966). F. Amer med. Ass., 198, 553.

Dalby, L., McDonald, R., and Sloman, G. (1967). Med. F. Aust., 1, 1255 .

D'Amato, H. E., and Truant, A. P. (1955). Arch. int. Pharmacodyn., 101, 113.

Dotter, C. T., and Straube, K. R. (1962). Amer. F. Roentgenol., 88, 27.

Frieden, J. (1965). Amer. Heart \%., 70, 713.

Harrison, D. C., Sprouse, J. H., and Morrow, A. G. (1963). Circulation,

28, 486 .
Lown, B., Vassaux, C., Hood, W. B., Fakhro, A. M., Kaplinsky, E., and Roberge, G. (1967). Amer. 广. Cardiol., 20, 494.

Robinson, J. S., Sloman, G., and McRae, C. (1964). Med. F. Aust., 1, 427.

Valori, C., Thomas, M., and Shillingford, J. P. (1967a). Lancet, 1, 127.

Valori, C., Thomas, M., and Shillingford, J. P. (1967b). Amer. Y. Cardiol., 20, 605 . 